\title{
Transatlantica
}

Revue d'études américaines. American Studies Journal

1 | 2017

Morphing Bodies: Strategies of Embodiment in

Contemporary US Cultural Practices

\section{An Interview with Jonathan Franzen}

Jérémy Potier

\section{(2) OpenEdition}

Journals

Electronic version

URL: https://journals.openedition.org/transatlantica/8943

DOI: 10.4000/transatlantica.8943

ISSN: 1765-2766

Publisher

Association française d'Etudes Américaines (AFEA)

\section{Electronic reference}

Jérémy Potier, "An Interview with Jonathan Franzen", Transatlantica [Online], 1 | 2017, Online since 29 November 2018, connection on 20 May 2021. URL: http://journals.openedition.org/transatlantica/ 8943 ; DOI: https://doi.org/10.4000/transatlantica.8943

This text was automatically generated on 20 May 2021.

\section{(c) (i) (9)}

Transatlantica - Revue d'études américaines est mise à disposition selon les termes de la licence Creative Commons Attribution - Pas d'Utilisation Commerciale - Pas de Modification 4.0 International. 


\title{
An Interview with Jonathan Franzen
}

\author{
Jérémy Potier
}

1 Jonathan Franzen is the author of five novels-The Twenty-Seventh City (1988), Strong Motion (1992), The Corrections (2001), Freedom (2010) and Purity (2015)-as well as of a memoir, The Discomfort Zone (2006). He regularly writes essays for The New Yorker and other magazines. To date, two collections of Franzen's essays have been publishedHow to Be Alone (2002) and Farther Away (2012). A third collection will be published in November 2018. In 2001, The Corrections was awarded the National Book Award and the James Tait Black Memorial Prize. The novel was also a finalist for the 2002 Pulitzer Prize, the 2001 National Book Critics Circle Award for Fiction, and the 2002 PEN/ Faulkner Award. Jonathan Franzen is a member of the American Academy of Arts and Letters, the French Ordre des Arts et des Lettres and the German Akademie der Künste.

2 The following interview is the transcript of a Skype conversation that took place on March 12, 2018. It was then edited over a series of e-mail exchanges.

Jéremy Potier: You've written a great many essays on a variety of topics. Your third
collection of essays will come out in November. In 2013 you published a book-length
translation of essays by the Austrian satirist Karl Kraus. You were also acted the guest
editor of the 2016 edition of The Best American Essays. What's the role of essay writing in
your work as a novelist? Does the research that is carried out for the essays become
material for fiction? Jonathan Franzen: There is also my memoir, The Discomfort Zone, which began as essays as well. So, in fact, I'll have soon published as many non-fiction titles as novels. It's strange, because I didn't intend to be an essayist at all. Until the mid-1990s I had a strong commitment to not writing non-fiction. But I needed money, and so I started doing journalism for The New Yorker, and little by little I developed a tone, or a persona, in which I could talk directly about myself, which I've never been able to do in fiction. And this was a liberating discovery. I'm an opinionated person-I move through the world and I have strong opinions about things-and it was liberating to express my opinions and to get a response in a matter of days or weeks, rather than two years or five years or seven years. It also took a huge amount of pressure off the novels. I could focus more purely on story, and I didn't have to worry that by working on a novel I was ignoring the world. One of the unbearable things for the novelist 
nowadays is that cultural change is rapid and novels are slow. The essays have become a way for me to keep up with culture in the moment.

JP: Your first two published novels-The Twenty-Seventh City and Strong Motion-have often been referred to as "system novels." These were sprawling, heavily plotted works. In a later essay-"Why Bother?" (1996)-you expressed your "desire to write about the things closest to [you], to lose [your]self in the characters and locales [you] loved" (Franzen, 2002, 95). The scope of The Corrections is indeed much more restricted than the one you adopt in your earlier fiction. Did you set aside the ambition to write sweeping, totalizing novels at that point?

JF: Yes. "Why Bother?" documented the abandonment of my ambition to map the entire world onto a novel. A novel that tries to do this necessarily becomes very large, and every time I would think I had the world entirely mapped I would discover another important aspect of the world that needed to be included, and the outline for the novel would get even longer, and, of course, the longer the outline gets, the longer the book is going to take to write, which means that it will be even more out of date by the time it's finished. I finally realized what a losing game it was to chase after social reality. It also just wasn't fun anymore. I had a feeling of doing it because I was supposed to do it, because it was what the novels that were critically privileged in the United States in the 1970s and 1980s had done. I had dutifully represented social reality in my first two books, and it was simultaneously the least fun part of the work and the easiest part to do, because all I had to do was read the newspaper and watch TV and regurgitate what I already knew. It was much more fun to go on an adventure-to dive into parts of myself and parts of my experience that a non-writer would be at pains to avoid because they're scary and upsetting. And I discovered that there was, after all, a way to represent social reality in a novel: not through its direct depiction but through its miniature reflection in the soul of a character. Once I set down the burden of "reporting" on the world and focused on character and story, writing novels became fun again.

JP: Yes, and I'd like to touch upon the distinction you draw between story and plot a bit later in the conversation. A recurring subject matter of yours is the American family. It seems to me that you have a special interest in what the form of the family allows for in terms of narrative strategies. Focusing on the family is arguably a way of bringing together independent yet interconnected stories. Likewise, starting from the small microcosm of the family, you seem to work out points of connection with society at large. Is that a way of considering the bigger picture without giving up on specifics?

JF: It does function that way. In The Corrections, I had three adult children to work with, and each of them belonged to a different kind of world: Denise to the restaurant world, Chip to the academic world, Gary to the business world. This is what happens in families-children specialize in different things, by way of individuating themselves. Although, as I say that, I realize that my dentist in New York has three brothers, all of whom are FBI agents. But that's unusual. In most families, the kids try to distinguish themselves from their siblings. This is nice for a novelist, because, if you're painting on a fairly large canvas, it gives you different colors and flavors to work with. It allows me to be a social novelist, in a sense, but not a didactic social novelist, not an instructive social novelist. I'm not serving social reality, I'm making its particulars serve me.

But to the family question. Every time it comes up in an interview, I make the same claim, which is that I'm not a family novelist. In The Corrections, supposedly a "family 
novel," the only family we really see interacting is Gary's. The original five Lamberts are together in the same room only for about six pages, near the end of the book. Yes, they're in relation to each other, and, yes, they have feelings about each other, but we see almost nothing of their actual family life. They're five independent actors whom I happen to have organized according to their family ties. It's a convenient way to organize them-you could even say it's a lazy way. If I take two randomly chosen individuals and try to tell a story about them, I have to invent a plot that brings them together, and it takes a very strong plot to generate the kind of strong feelings between characters that a family generates effortlessly. In a family, everyone has strong feelings about each other. With families, it's also really easy-again, this goes to my laziness-to create significance. One goal of the novelist is to maximize the possibilities for meaning in a text, and it's immediately more meaningful to compare and contrast two people who are genetically related than two unrelated people. Maybe I should give a specific example? There's Gary Lambert, who is Alfred Lambert's son. As soon as you know that this man is this other man's son, you start thinking, "Well, in what ways is he like his father?" There's a huge field of potential meaning right there. And then there are second-order fields of meaning, because Gary himself knows that he might be like his father. He may be afraid of this; he may be motivated to demonstrate that he is not like his father. All of this happens almost effortlessly as soon as you posit a family relationship in a book. Family is a signification-rich structure! The writer can tap into universal conflicts just by writing the words "son" and "father."

Ten years ago, when I started to play the guitar, a guitarist friend of mine instructed me to listen carefully to rock songs and try to figure out what the guitarist was doing. He said, "I guarantee you that that guitarist is doing it the easiest possible way. Wherever there's a shortcut to be taken, I guarantee you that the guitarist is not doing it the harder way." And it's like that for a novelist, too. For me, the family is just easy: it's a shortcut to intensity and significance. It spares me a lot of work that I can then put into other aspects of the writing.

JP: Well, you might have begun to answer my next question. Sections of your novels first appeared in The New Yorker or The Paris Review as independent narratives. The overall structure of The Corrections is reminiscent of a series of interlocking novellas. The final chapter of Freedom-where Walter retreats to his Walden-like pond-reads a lot like a short story to me. And yet, you've never had a collection of stories published. Why are you so faithful to the form of the novel? Is it just because it allows for comfortable room for character and plot development? I feel that these constructions bring in another dimension to your work: they allow you to examine the intersections between various versions of a story, and various timelines. Would you agree?

JF: Yes. Much of the attraction of the novel for me has to do with the development of characters over time-over years or decades. That's harder to manage in a short story. It's also difficult, in a short story, to include more than one point of view, and next to impossible to include more than two. Both of these limitations give me a kind of claustrophobic feeling when I try to write a story. What seems true now may not seem true ten years from now, and what seems true from one person's point of view may not seem true from her husband's or her son's. If meaning in fiction is an ndimensional space, time and point of view are two axes I can't seem to do without.

That said, I have tried to write stories. I wrote about thirty not very good ones when I was starting out as a writer, and I collected hundreds of rejection letters from various 
magazines. More recently, I published a couple of strange little stories in The New Yorker and The Guardian, but that hasn't added up to a collection. I'm sadly aware of not having what Trevor and Welty and Chekhov have-a boundless sympathy for ordinary people. Chekhov seemed like he could have kept writing short stories forever and never run out of material, because the world of ordinary people was endlessly interesting to him. A country doctor mattered to him as much as the Tsar or Anna Karenina. Unfortunately, that's not a gift I have, so I've stayed away from stories.

\section{JP: What about Alice Munro?}

JF: I was going to mention Munro, except that, as I've written about her, ${ }^{1}$ she sort of tells the same story over and over again. Her particular genius is to make it seem like a new story each time. I actually think her work is more about herself than, say, Chekhov's is about himself. Although, of course, he was a doctor.

JP: As you've just suggested, you tend to favor multiple perspectives. In your novels, focus constantly shifts from one character to another. At times in the flashback section of The Corrections, the point of view switches with each new paragraph. I was about to ask whether this instability of viewpoints was a way of articulating the complexity of contemporary American experience within an overall realist framework. But perhaps you'd like to comment on the term "realist" first?

JF: I am a realist novelist! But let me go back to your previous question and say one more thing. A big discovery for me in the 1990s was how much I loved short novels. A short novel typically observes the classical unities-time, setting, and action are all compressed-and it builds inexorably to a dramatic crisis. There's nothing better than dramatic crises! But, unless you're Dostoevsky, you can't have a crisis that goes on for 500 pages. Even Dostoevsky wrote novels that were collections of novellas or, maybe more accurately, three- and five-act dramas. So what I've found myself doing again and again, ever since the mid-1990s, is trying to create larger novels by bundling together multiple short novels, which keeps the intensity level high while letting me deploy multiple points of view.

There is indeed that passage in The Corrections where we get a different point of view with every succeeding paragraph. I'd recently read the second section of DeLillo's Underworld, where Nick Shay is sorting his household garbage, putting plastic in the plastic bin and glass in the glass bin. DeLillo happened on this strange technique where, instead of having a series of paragraphs all on the same subject, followed by another series of paragraphs on a different subject, he shuffled all his paragraphs together and bounced from one subject to the other to the other to the other. I thought that was really cool; it's actually my favorite part of Underworld. So, in that passage in The Corrections, I experimented with using the free-standing paragraph as the fundamental unit on the page. It seemed OK to borrow one trick from DeLillo in a novel that otherwise amounted to a declaration of independence from his generation of American novelists.

As a reader, I prefer the kind of "realism" in which characters behave in a recognizably human way and operate in a recognizable world. It's much harder for me, both as a reader and as a writer, to invest in a narrative in which people are doing things I wouldn't do in real life or in a world that's so absurd that I don't recognize it. A basic level of realism is the prerequisite for having an emotional 
response to a work. The problem I had with a lot of postmodern fiction was that I was reading stories I didn't care about, because I had no realistic purchase on them.

JP: Speaking of a recognizable world, I'd like to dwell on one of the recurring locales of your novels: the self-effacing suburbs of Midwestern America. It has been argued that a key trend in the history of North-American literature is an urge to explore unknown territories-I am thinking of the wilderness of Melville, Twain or Hemingway, of course, but also of the chiaroscuro of the modern city. In the suburbs, however, everything seems to be so obvious and static, so familiar. So, how does this impulse to set out and explore respond to suburban North-America?

JF: That's a good question. I might object that there aren't very many suburbs in my work. There's nothing suburban in Purity. Nothing in Freedom either; the Berglunds are urban gentry. Strong Motion is set in Somerville, which is literally a suburb of Boston but is basically urban. So really what we have is the St. Jude parts of The Corrections, and the entirety of The Twenty-Seventh City. In the latter, I was facing exactly the problem you've described. The suburbs were invented to avoid the kinds of interesting dramas that you get in the wilderness and the city. The suburbs are about safety, continuity, health, and, in America, racial segregation: you don't have to confront people who aren't like you. So there I was as a 22-year-old kid, trying to build a novel out of the only experience I had, which was suburban. My parents were totally devoted to their kids, and we were raised in a nice, safe suburb with good schools. There was nothing obviously interesting about that setting, which is why I had to bring in some Indians to try to wreck the place. Or, more precisely, to make the suburbs strange. When the Indian character Singh is following around Probst's daughter, Luisa, he could be an astronaut trying to make sense of life on Mars. That was my best shot as a 22-year-old at trying to make something interesting out of a place that was designed to be not interesting.

The suburbs do reappear in The Corrections, because by that point I'd realized that they were more interesting than I'd given them credit for. I think there's a Roxy Music song called "In Every Dream House a Heartache." The heartache of the suburbs was obvious enough in the stories of John Cheever and John Updike, but I didn't recognize those writers' suburbs, in part because they were so vividly Connecticut and Massachusetts, and in part because my parents weren't drinkers or adulterers. It took the aging of my parents to show me the heartache of my own suburb. Once the kids are out of the house, once the parents are in their seventies, things can suddenly begin to resemble Samuel Beckett-these now childless couples living out their days in an ever more desperate endgame. Of course, this could be taking place anywhere, but the fact that it's in the suburbs, where everyone is supposed to be nice and everything is supposed to be comfortable, makes the suffering all the more jarring and poignant.

JP: In The Corrections, much of the action occurring in the suburbs actually unfolds underground, in basements. One of your characters is said to adopt "an essentially archaeological approach" (Franzen, 2001, 168) while sorting out his old toys in the basement of his parents' house. Would you say that approaching suburbs as antiquated objects is a way for you to reveal further potential fields of meaning?

JF: The line in The Corrections is "And so [...] life came to be lived underground" (Franzen, 2001, 10). The literal reference is to Alfred and Enid's house, in which, on the main floor, there's no clutter and no dirt but also no actual living of life; all the living was happening in the basement. So, very literally, underground. There's a 
tragic dimension to that. If you grant that the endeavor of the suburbs is to make life superficially more pleasant, but you believe that life is fundamentally not so pleasant, you're going to find yourself searching for truth in the basement.

JP: Would that be an example of what you've termed "tragic realism" (Franzen, 2002, 91)?

JF: Tragic realism is a view of the world which derives from classical tragedy, and it essentially makes two claims. One is that we can't know everything. We may think we know things, but we can't really know them, particularly morally. Moral epistemology is a nightmare, if only because we all move through the world believing that we're good people, but nobody can be certain that he or she really is a good person. The other claim is that fate can't be escaped-that the fundamental contradictions of human existence can't be resolved. The tragic realist is naturally at war with the infernal modern wedding of technology and consumerism, with its promises of perfect knowledge and purchasable solutions to the problem of existence.

JP: Time seems to have stopped in St. Jude, and yet the narrator ironically insists that it has not really: the place is decaying, the food that is hoarded in the basement has turned practically poisonous... Still, Enid and Alfred keep living in the house, on self-delusion, oblivious to "the sag of entropy" (Franzen, 2001, 174) all around them, like dreamers. Through a series of metaphors, the ordinary suburban house is transformed into a place that has fallen under an enchantment of sorts. Isn't there something evocative of The Great Gatsby in this relationship to the past and to past memories?

JF: I use the word "enchantment" a number of times in The Corrections. Denise talks about it, or Denise thinks about it and we get her thoughts. In children's literature, enchantment refers to the casting of a spell, and the result of the spell is often that characters or places become frozen in time. You know, Snow white goes to sleep for years while the rest of the world moves on. In Denise's recollection, the house in St. Jude has something fairy-tale-like about it. Her parents' personalities seem giant to her, and she has a recollection of extraordinary things happening around her, primal conflicts unfolding in the course of an ordinary day. To Denise, Alfred and Enid and the house have remained frozen in time. To Alfred and Enid themselves, it may be more like "Waiting for Godot." Their life is an unfunny comedy of terrible little problem after terrible little problem: a thousand crickets magically appear in the basement, cans of pee magically accumulate on the laboratory bench. The house is like a bad dream they're stuck in. And Alfred's response is often to fall instantly asleep, like a person under a spell. Enid's response is to retreat into a fantasy world. Reality's breaking of the spell of the Lamberts is the fundamental action of the novel.

JP: I'd like to quote from The Corrections at that point: "The odd truth about Alfred was that love, for him, was a matter not of approaching but of keeping away" (Franzen, 2001, 526). Throughout the novel, the narrator hints that staring at things for too long or too often might turn out to be harmful. As in Proust's novels, your characters eventually come somewhat closer to an understanding that what they see is made up of projections and memories: "The world in the windows looked less real than Enid would have liked" (Franzen, 2001, 476). Do you mean to imply that in order to preserve the vision, or the memory, of an object, the object itself has to be kept at bay?

JF: Well, let's think about that. We can start by agreeing that Proust was right: what matters is not the real thing but what the mind makes of it. The object that you're remembering is dead; it's your memory of the object that is alive. 
One way of looking at a novel is as a supplier of artificial memories. A novel activates the same part of your brain that memory activates. If I say there was a red Volkswagen parked in the street, the reader may call to mind a bright red Volkswagen parked in a street. But what does that mean? In most cases, when you recall something, or imagine something, you're summoning up a cartoon version of it. It's not like, when you shut your eyes, you're watching a high-definition movie and can move your eyes around and can examine everything in detail. What you're calling up is more like redness and Volkswagenness. And that's fundamentally how writing works. Picture me sitting in my office. I'm not looking at any red Volkswagen parked in the street. I'm looking at a window whose blinds are down, and it's dark in here and I can't really see anything except the screen in front of me. So when I write about a red Volkswagen parked in the street, it's already something I'm remembering. I'm not out there with a camera, and I'm not one of those writers who goes out with a notebook and studies an object and writes down a description. I'm using the memory circuits in my mind, translating one form of compression into another, memory into language, and hoping that the words will activate similar circuits when they're read. The entire process takes place at a remove from real objects.

JP: And fiction in turn fashions the human brain...

JF: Absolutely. The great works of fiction for me are the ones where I feel that I've been through an experience. A memory of something was implanted in my brain as if I had experienced it myself. That's the highest goal for a fiction writer. It's important to note that, because our brains don't have Cloud storage capabilities that can record all sensory data from our entire lives, we have radically simplified memories. Our brains are fundamentally cartoonists. We retain essences, not replicas. And I think, as a novelist, I understood this very early on: in order to make a strong impression in the reader's brain, the characters have to be distilled into extreme versions of themselves. Genuine "realism" in fiction would be a very boring thing. Most days of a person's life are unremarkable, and most of the things she does or says are unremarkable. To create a memorable experience with a novel, you have to exaggerate and repeat a small number of character traits; you have to choose the most extreme days of a character's life and ignore the rest. Good dialogue, too, is rarely "realistic." It has to be plausible enough that it doesn't disturb our sense of verisimilitude, but it's much more concentrated, and funnier, and more precise, than anything in a real-life conversation would be. The goal with every aspect of a novel is to "make it extreme"-as extreme as you can get away without offending the reader's sense of what's possible in the real world.

JP: It strikes me that there are a great many Promethean figures in your novels. In The Corrections, Chip edits a script that he has put together, Enid is metaphorically linked to an alchemist, Alfred is of course an inventor tinkering with a variety of materials, while Denise is a food artist. In Freedom, Patty writes her autobiography, which, revealingly enough, is both framed within the main narrative and read by two characters. There are other examples in your novels. Does this mean that we all invent our own version of reality, tinkering with fragments of the sensible world? Do we create stories to live by, and if so, what's the role of writing and reading fiction in this process?

JF: I vowed as a young novelist that I would never write a novel that contains a novelist as a character. And yet I've been a novelist my entire adult life. It's the life I know, my friends are mostly writers, I live with a writer, and so it's hard to keep on creating characters without making them writers. I've had to cheat in various ways, 
making Richard a songwriter, Patty an autobiographer, chip a would-be screenwriter. In Purity, there are print journalists, a dissident poet, and another autobiographer. I don't think of myself as a particularly Promethean figure. It's more like I'm too lazy to think up better jobs for my characters.

Intertextuality is another dimension of novelistic meaning. Text within text, text as both story and as an object in the story-I don't have the theoretical vocabulary to talk about why it's so cool, but I know it is cool. It's part of the excitement of those epistolary novels in the $18^{\text {th }}$ century. The story of Pamela in Pamela is also the story of those letters, of where and how and why they were written, how they were delivered or not delivered, and where and how they were received. To make it happen, Richardson had to do without certain other dimensions of textual meaning, most notably the flexibility of tone and perspective that you get with free indirect thirdperson discourse, which later novelists developed into the crowning achievement of the novel. But nowadays it's not an either-or. You can use both text within text and free indirect discourse.

JP: There is arguably another form of text within the text near the end of The Corrections. The character of Denise has to look underneath a bench in order to read an inscription-a set of four letters-standing as proof of her past affair with one of her father's workmates. The inscription is the mark of both a secret and a fault, which can readily evoke The Scarlet Letter. Yet, when Hawthorne's letter is meant for public humiliation, the letters penciled under the Lamberts' bench remain unvoiced by Alfred, who wishes to preserve his daughter's privacy. Paradoxically, then, what validates the existence of the fault turns out to be symbolic of a respect for privacy. Would you like to comment on this "correction" of the original motif? Privacy and secrets, concealment and revelation are strong undercurrents in your work, especially, of course, in Purity...

JF: One of those questions too beautiful to sully with an answer.

JP: In Freedom, a central concern repeatedly voiced by the character of Walter is the notion that the American Continent is finite. Urban sprawl is thought of as a force that paradoxically both fragments and creates a sense of homogeneity, posing a threat to diversity, and indeed to biodiversity. As a novelist, what is your reaction to this metamorphosis of the American landscape?

JF: I have a stronger reaction as somebody who cares about birds. I think it's environmentally bad; I think people should live in high-density settlements with lots of wild space around them. Instead, various political and economic currents in America have resulted in the opposite, this horrible sprawl, which is long-term unsustainable and short-term incredibly destructive of the natural world. But as a novelist? Homogeneity-what Lévi-Strauss called cultural entropy-is the enemy of art. If the novel is a gathering-together of as many dimensions of meaning as possible, in one highly condensed, compelling package, that's a good description of what you're doing when you're reversing entropy. You're creating intense order. Already, when I was 21, I was worried about cultural entropy. I was looking for ways to combat it and seeing novels as my way of doing that. My literary (and environmental) wish to compress things, and to maximize the voltage between differences, was part of my long love affair with cities. Cities aren't just more environmentally responsible than sprawl. They're more interesting.

JP: And you've drawn a parallel between the city and the novel in How to Be Alone, describing them both as offering "maximum diversity and contrast packed into a single exciting experience" (Franzen, 2002, 80). Do you feel that writing the city-its crowds and monuments, its virtually boundless potential for stories-and perhaps especially writing 
New York City, "the biggest and most city-like city in the world" (Franzen, 2012, 253), calls for specific techniques, specific rhythms and images?

JF: This is probably the place to confess that I'm over my love affair with cities, at least big ones. I now live in a city of less than 60,000 people, Santa Cruz, and I'm happy here. For a while, when I would go back to New York, I would notice that my heart didn't lift the way it used to when I took a cab into Manhattan from the airport. More recently, it's gotten worse than that. I now feel actively repelled by Manhattan, which has been taken over almost entirely by banks and mega-rich foreigners. The only things I still like are the city's racial and ethnic diversity, and Central Park, which fills up with a remarkable diversity of bird life during spring and fall migration.

JP: I'd like to dwell on birds, which is a key concern in Freedom. It has been argued that one way of looking at contemporary literature is to think of it as a medium whereby a struggle against inattention can be enacted. Fiction involves a process of selection. It follows that what the author decides to be worthy of representation is necessarily a commitment of sorts, the expression of a form of ethical positioning. This seems to echo some of the concerns that you voice in Freedom: "Every species has an inalienable right to keep existing" (Franzen, 2010, 219). In the novel, the mere act of naming a specific bird-the Cerulean Warbler-strikes me as a form of commitment. The endangered bird now belongs to the world of the readers of Freedom. Would you agree that the powers of naming can be linked to ethics in such a way?

JF: Maybe. For me, the central ethical imperative is to consider the possibility that I'm wrong, which is simultaneously to consider the possibility that people I disagree with are right. The situation that most interests me in books is one in which each side thinks the other is wrong, and they're both right and they're both wrong.

I do think that most ethical systems try to promote attentiveness. What we call a jerk is somebody who is inconsiderate, which means they're not thinking about other people-they're not paying attention; they're leaving their dirty laundry on the floor; they're not flushing the toilet or whatever; they're shifting lanes on a highway without looking to see if anyone's there. So inattention has always had a negative moral connotation. The central goal of certain strains of Buddhism is simply to pay attention, and my favorite Christian, St. Francis of Assisi, paid attention to the smallest lark and swallow. But, interestingly, most spiritual forms of attention are not about naming. I think in ideal Zen Buddhist practice you'd be paying close attention to the Cerulean Warbler, but you would not be naming it. Sartrean Existentialism is inclined to consider the name an active impediment to experiencing the thing.

You've led me into realms of modern philosophy that I'm perhaps not particularly qualified to speak about, but I think the imperative for the fiction writer is a little different when it comes to naming things and bringing close attention to bear on them. I think it has more to do with trying to create an experience, trying to condense and intensify impressions in that almost cartoon-like way. When I write "Cerulean Warbler," the only question that matters to me is, Can you see it? Can you see why Walter might care about it? Richard Katz looks at the picture of the warbler on the literature that Walter and Lalitha give him, and he thinks, "Yeah, it's a blue bird. Doesn't look very smart." That's all he's got to say about it. And that fact about Richard is much more interesting to me, as a novelist, than the name Cerulean Warbler. 
JP: In Farther Away, you speak of details as "a way of connecting, on relatively safe middle ground, with another human being" (Franzen, 2012, 163), which in turn becomes one possible definition of literature. Is this something you consciously work on in your novels? Would you like to expand on the way you handle specifics in a work of fiction-as a writer but perhaps also as a reader?

JF: What could be safer than a book? It just sits on a shelf unless you open it. And yet, if you open it, it is literally the middle ground between the act of writing and the act of reading. But I think the specific quote you've mentioned comes from my eulogy for Dave Wallace. For Dave, probably because he was so angry, open emotional expression could be scary. He was always happy when he found somebody he could talk about practical things with in great detail, because it was presumed that the person talking about his area of an expertise loved that area of expertise. By listening to that person and showing interest, David was also practicing a certain kind of love, but he and the person didn't really have to relate to each other directly; it could all be done through the medium of the details.

It occurs to me that there's a similarity with Alfred Lambert there-a person who prefers to keep love implicit, unexpressed. I'm more comfortable with expressing love than Alfred or Dave, but I think part of the attraction of birds for me is that they're indifferent to me. I can pour my love into them without fear of getting entangled with them. They don't want to be touched. In fact, a lot of them try to avoid even being seen. And when I'm talking with another person who loves birds, we're often talking about the details of specific birds; the love is there in the details, but it stays implicit.

This is related but not identical to what literature does. When I say I'm paying attention to things, I usually mean that I'm paying attention to things inside me-to the things that make me the most uncomfortable, the things I'm most afraid of, or most ashamed of. I'm trying to render these things in a relatively safe form, usually by making them funny. I have in mind a reader who experiences the same things and feels alone with them and therefore reads about them with a sense of grateful recognition: "Yes, I have that fear, I have that shame, and I'm happy to know I'm not the only one." The key task for the writer is to detoxify the fear and the shame and render them readable, through humor and irony, or through the magic of inventing lifelike fictional characters. That's the "safe" middle ground that Dave and I were talking about.

JP: In a previous interview, you claimed that, with Purity, you had gone back to writing plots rather than stories. It seems to me that these terms foster two radically different visions of the world that you wish to offer as a novelist. In both The Corrections and Freedom you leave much room for the contingent and the incidental. Purity is more evidently driven by causality. The motif of the conspiracy is of course relevant in this regard. Would you like to say a few words on these two ways of weaving events together?

JF: It's true that, in Purity I went back to the kind of plotting I'd been doing in my first two books, and tried to do it better. That was a very conscious choice. I mean, I'm not apologizing for those first two novels, but they were the work of a young man who had a very strong, clear sense of morality which was then demolished by subsequent events in his life. And also, I felt that, in those books, particularly The Twenty-Seventh City, I had let the conspiracy plot determine what the characters did. Yes, I would take ten pages to go to a football game or a shopping mall, and kind of relax and just write about the character and the things that were going on in his life, but pretty 
soon I had to get back to advancing the plot, which required that he behave in certain ways.

The Corrections was my first rebellion against the tyranny of plot. The only way I could get that book written was to start with characters and try to define them in terms of their dramatic situation: by what they wanted and what was standing in the way of it. That's what I mean by story. Gary Lambert's definition as a character is not how tall he is or how much money he makes; it's that he's in mortal combat with his wife and is trying to demonstrate that he isn't clinically depressed. To me, that's not plot. It doesn't tell me that he needs to get to such and such point by page 30 and some other point by page 60 . It means, "Oh, that's a funny situation, I wonder how that's going to work out. Let's see how we can stress poor Gary in a way that makes it even harder for him to pretend he isn't clinically depressed, and then let's see what happens with him and his wife." As soon as I realized that this is what I should be doing as a novelist, focusing more on the page-by-page journey than on the plot-driven destination, I started having fun again. Writing became so much more of an adventure. You go to work in the morning and think, "Oh, what's going to happen now?" Obviously, I always have some idea of where the book is going. I know that the central conflicts have to lead to a crisis at some point, and maybe I have an idea of what the particular crisis will be. I may even throw in some little side-plots along the way, like Gary's attempt to extract value from his inside information about his father's patent. But what brings the pages alive and makes them fun to write is character, and the way you create a character is by figuring out his story, beat by beat.

So why did I go back to a conspiracy plot in Purity? Honestly, the book started with some odds and ends that I had in a drawer. I knew I had a German character I wanted to work in, I knew I had this terrible marriage between Tom and Anabel, and I knew I wanted to tell the story of that marriage. But I also knew that if I just told the story of the marriage no one would want to read the book. So Purity, as a whole, can be viewed as an elaborate package for Tom's account of what happened in that marriage. Many other things are going on, of course. Tom and Anabel don't even turn out to be the main characters. But, nevertheless, that was the impulse, and once I had the idea that Anabel would have had a daughter and not told her ex-husband that she did, I was already in the realm of plot. And it invited me to invent a complicated way for Tom to find out that he has a daughter, despite Anabel's almost perfect concealment of herself and Pip. The concealment seemed very characteristic of Anabel, so I had to keep that. The only solution I could think of was an old-fashioned conspiracy plot. I thought, "I haven't done one of those in more than twenty years, let's see if I can do it better this time."

One of the things I'd learned in twenty years was that the best motives are irrational. A lot of my earlier impatience with plots had had to do with how mechanistic they feel-the gears of story turning because Character $\mathrm{X}$ wants to win an election and Character $\mathrm{Y}$ wants money. In a story where plot is central, comprehensible motives reduce the potential for meaning in a narrative-at the end, all you're left with is the machinery. Immersion in story had opened my eyes to the beauty and mystery of silly or irrational motives. Which are also, not incidentally, more common and thus "realistic" than rational motives. People are constantly doing outrageous shit for terrible reasons. 
Another thing I'd learned was to plot late, not early. With The Twenty-Seventh City, I actually started with the idea, "Indians come to St. Louis, Missouri, and conspire to take over the city." In Strong Motion, too, before I'd written a single word, I'd had this idea of an earthquake happening in Boston. With Purity, I started with the story of Tom and Anabel, plus a vivid sense of who Andreas was. The plotting came later, in the context of important things I already knew about the characters.

JP: May I ask you if you're working on a new project?

JF: I am working on a new novel, as of a couple of weeks ago. I was finishing up some non-fiction work until last month-the last piece of this new collection. So, I have a new novel; I've even sold it to some publishers on the basis of a three-page description. So I have no choice but to write it.

JP: Thank you so much.

JF: Thank you. It's been a pleasure.

\section{BIBLIOGRAPHY}

FRANZEN, Jonathan, The Twenty-Seventh City, New York, Farrar, Straus and Giroux, 1988.

---, Strong Motion, New York, Farrar, Straus and Giroux, 1992.

---, The Corrections, New York, Farrar, Straus and Giroux, 2001.

---, How to Be Alone. Essays, New York, Farrar, Straus and Giroux, 2002.

---, The Discomfort Zone. A Personal History, New York, Farrar, Straus and Giroux, 2006.

---, Freedom, New York, Farrar, Straus and Giroux, 2010.

---, Farther Away. Essays, New York, Farrar, Straus and Giroux, 2012.

---, ed. and trans., The Kraus Project, New York, Farrar, Straus and Giroux, 2013.

---, Purity, New York, Farrar, Straus and Giroux, 2015.

---, ed., The Best American Essays 2016, Boston, Houghton Mifflin Harcourt, 2016.

\section{NOTES}

1. In a review of Runaway (2004) first published in The New York Times in 2004 and later collected in Farther Away. See Franzen, 2012, 283-296. 


\section{AUTHOR}

\section{JÉRÉMY POTIER}

Université Toulouse - Jean Jaurès 